\title{
Process Simulation on Fast Pyrolysis of Palm Kernel Shell for Production of Fuel
}

\author{
Mangala Nayaggy ${ }^{1}$, Zulfan Adi Putra ${ }^{1 凶}$ \\ ${ }^{1}$ Chemical EngineeringDepartment, Universiti Teknologi PETRONAS, 32610 Bandar Seri Iskandar, Perak. \\ Malaysia \\ Correspondence: E-mail: zulfan.adiputra@utp.edu.my
}

\begin{abstract}
A B S TRACT
As the worlds primary source of energy is depleting, an alternative particularly renewable energy is being explored. This work is a preliminary study on fast pyrolysis process of palm kernel shell to produce liquid fuel. The simulation uses pyrolysis data obtained from one of the previous works on fast pyrolysis of palm kernel shell. As there are no literature available on upgrading of bio oil from fast pyrolysis of palm kernel shell, the chemical reactions are synthesised based on upgrading of bio oil from different biomass. The upgraded oil is then analysed by comparing its distillate curve with that of the ASTM of gasoline. The distillation curves are shown to be quite similar as the components found in the oil almost resemble those in the gasoline. Thus, the bio oil from fast pyrolysis of palm kernel shell has almost similar components compared to the ASTM of gasoline.

(C) 2019 Tim Pengembang Jurnal UPI
\end{abstract} \begin{tabular}{l}
\hline A R T I C L E I N F O \\
\hline Article History: \\
Submitted/Received 29 Nov 2018 \\
First revised 01 Jan 2019 \\
Accepted 07 Mar 2019 \\
First available online 09 Mar 2019 \\
Publication date 01 Apr 2019 \\
\hline Keyword: \\
Palm kernel shell, \\
Fast pyrolysis, \\
Bio oil upgrading, \\
Hydrodeoxygenation, \\
Simulation
\end{tabular}

\section{INTRODUCTION}

The world energy demand is estimated to increase by $28 \%$ by 2040 . Meanwhile, fossil fuel which is the primary source of energy is depleting (Andika and Valentina, 2016). Hence, renewable energy especially biomass is being explored as the alternative. In Malaysia, one of the most commonly found biomass are from oil palm industries. The waste mainly consists of empty fruit bunches (EFB), palm kernel shell (PKS), oil palm fronds (OPF) and oil palm trunks (OPT). About 83 million of oil palm biomass were produced back in 2012 and estimated to reach 100 million by 2020 (Awalludin et al., 2015).

One of the ways to utilize this waste is through pyrolysis. The three products of pyrolysis are gas, char and oil. Pyrolysis can be categorized into fast, slow and catalytic. 
Slow pyrolysis produces mostly chars (Bridgwater, 2012) while catalytic pyrolysis has not much effect on the bio oil yield (Lim and Andrésen, 2011). Thus, fast pyrolysis is the most suitable method to produce bio oil (Bridgwater, 2012).

The oil produced however cannot be directly used as fuel due to high oxygen content and reactive nature (Bridgwater, 2012). There are a few upgrading methods to make the oil compatible to be used as fuel. These are hydrodeoxygenation (HDO), catalytic cracking, integrated hydropyrolysis and hydroconversion $(\mathrm{IH} 2)$ and emulsification.

In catalytic cracking, the conceptual chemical reaction shows that oxygen is removed as water and carbon dioxide at high temperature (Bridgwater, 2012). The common type of catalyst used for this process is zeolite and modified metals (Zacher et al., 2014). Yet, the oxygen content in bio oil is still significantly high. This is reported due to the formation of coke on the catalyst surface (Elliott et al., 2009).

Apart from that, integrated hydropyrolysis and hydroconversion $(\mathrm{IH} 2)$ is the recent technology used for bio oil upgrading. In this process, the biomass is pyrolysed at high temperature with pressurised hydrogen. The catalysts used for this process is obtained from the CRI Catalyst Company. The oil obtained has a low oxygen count (<0.5 wt\%) (Marker et al., 2012).

Emulsification is the combination of diesel with bio oil to produce biodiesel. Emulsification requires the aid of surfactant as bio oil is immiscible in hydrocarbon (Xiu and Shahbazi, 2012). Through this, the bio oil can be directly used as fuel, however study reported that the corrosiveness of the biodiesel is too high causing this method to be economically unfeasible (Xiu and Shahbazi, 2012).
Hydrodeoxygenation (HDO) removes oxygen as water using pressurized hydrogen at high temperature (Bridgwater, 2012). This is the most common technology used for bio oil upgrading. The typical catalyst used are CoMo and NiMo. Several studies have also investigated using different types of metal catalyst. The overall conversion is satisfying as the oxygen content in bio oil is greatly reduced (Elliott et al., 2009; Luo et al., 2016).

This work is a preliminary study that models a complete fast pyrolysis process, including upgrading the oil through hydrodeoxygenation to produce fuel. The feed for this study is palm kernel shell (PKS) and the experimental data is obtained from Nurul Islam et al., 1999). This study also covers the synthesis of chemical reactions for the hydrodeoxygenation process and also the comparison on the distillate curve of the simulated process with the ASTM of gasoline.

\section{MATERIALS AND METHODS}

\subsection{Methodology flowchart.}

Figure 1 shows the flowchart for the overall methodology. Firstly, data on the bio oil components and the pyrolysis product yields are obtained (Nurul Islam et al., 1999). Then the hydrodeoxygenation (HDO) reactions for each of the bio oil components are synthesized.

Next, the entire process starting from the pretreatment of biomass until the separation process is simulated in Aspen Plus V8.8. Lastly, the distillate curve of the process obtained from the simulation is compared with the ASTM of gasoline.

\subsection{Chemical reactions.}

The two main reactions taking place in the process are pyrolysis and hydrodeoxygenation (HDO). The chemical reactions involved in both the reactions are further explained. 


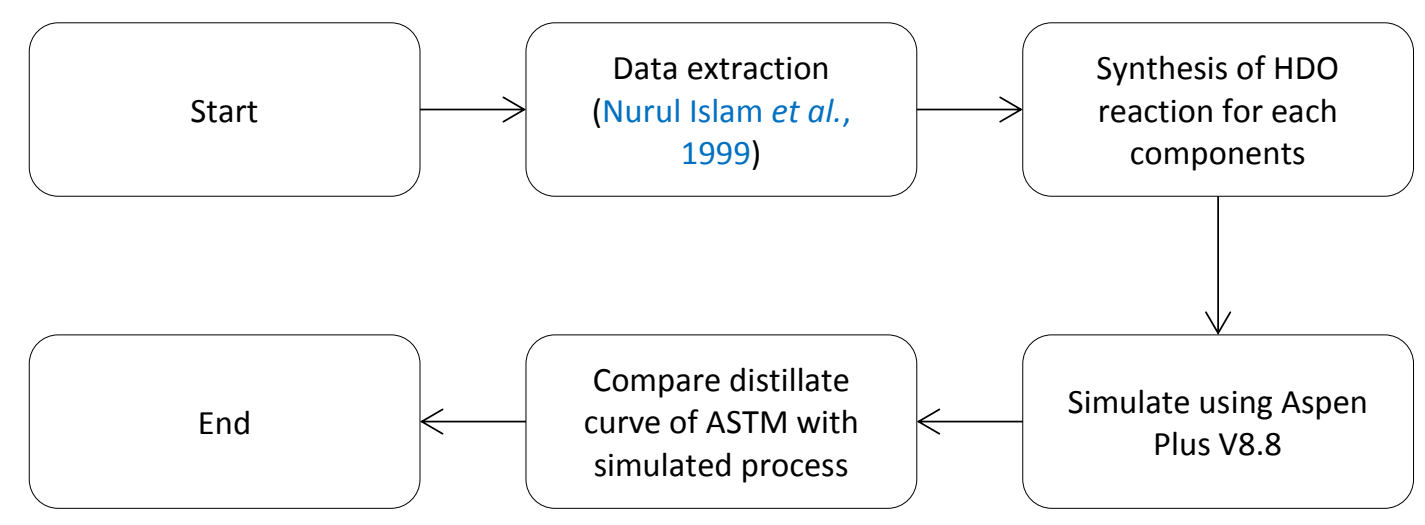

Figure 1. Flowchart on the methodology used

\subsubsection{Pyrolysis}

Pyrolysis is the thermal degradation of biomass at high temperature in the absence of oxygen. The three products of pyrolysis are oil, char and gas. In this work, the product yields tabulated in Table 1 are obtained from Nurul Islam et al. (1999).

\subsubsection{Hydrodeoxygenation (HDO)}

Hydrodeoxygenation (HDO) is an upgrading technique to convert the bio oil into transportation fuel. The operating conditions required for this process is at high temperature and high pressure (Elliott et al., 2009). Generally, hydrodeoxygenation process consist of hydrogenation and hydrocracking, however for simulation purpose, it is assumed to be a single reaction termed as hydrodeoxygenation (HDO).

In this work the hydrodeoxygenation (HDO) reactions are synthesised based on hydrodeoxygenation of different types of biomass. The bio oil components in Table 2 are used in this study.

Some of the components are not found in Aspen (indicated in Table 2). Thus, the compositions of these components are included with heavies.
For those components without literature on the hydrodeoxygenation process, it is determined using conceptual reaction reported by Bridgwater (2012). The heavies reported are replaced with dibenzofuran, $\mathrm{C}_{12} \mathrm{H}_{8} \mathrm{O}$ (dummy component) that has highest boiling point compared to the rest and a polycyclic nature.

Most importantly, from the synthesized reaction shown in Table 3, it is observed that the upgraded bio oil produced has a highest carbon number of 12 . Thus, it is impossible to obtain diesel ranged hydrocarbons from this oil. At the same time, there are no literatures available to support this statement as the upgrading of pyrolysis oil from palm kernel shell is yet to be explored.

\subsection{Process design}

The operating conditions for the pyrolysis reactor and hydrodeoxygenation (HDO) reactor are given in Table 4 . These conditions are used to simulate the process in Aspen Plus software. The process design methodology used in this paper is the same as in the literature (Bhullar and Putra, 2017; Putra, 2016a, 2016b). 
67| Indonesian Journal of Science \& Technology, Volume 4 Issue 1, April 2019 Page 64-73

Table 1. Pyrolysis product yields

\begin{tabular}{lc}
\hline Product & Yields (wt\%) \\
\hline Gas & 16 \\
Char & 26 \\
Bio oil & 58 \\
\hline
\end{tabular}

Table 2. Bio oil components (Nurul Islam et al., 1999)

\begin{tabular}{lc}
\hline Bio oil components & Composition (wt\%) \\
\hline 2-Methyl propane & 0.52 \\
Acetic acid & 16.90 \\
23-Hydroxy-2-propanone & 7.78 \\
22-Methyl penthyl ether & 0.84 \\
${ }^{1}$ Butandial & 2.13 \\
2Allyl acetate-2-ene & 4.73 \\
2-Furanaldehyde & 4.41 \\
2-Butanone & 0.84 \\
Methyl crotonate & 2.69 \\
Cyclopetanone & 1.34 \\
Phenol & 28.3 \\
13-Methyl cyclopentanedione & 1.38 \\
2-Methyl phenol & 0.79 \\
2-Methoxy phenol & 4.82 \\
4-Methyl 2-methoxy phenol & 2.02 \\
Ortho-hydroxy phenol & 2.16 \\
4-Ethyl 2-methoxy phenol & 1.09 \\
2,6-Dimethoxy phenol & 2.75 \\
4-Propene 2-methoxy phenol & 1.36 \\
Heavies & 15.76 \\
\hline & \\
&
\end{tabular}

Note: ${ }^{1}$ Not found in Aspen Plus 
Mangala Nayaggy \& Zulfan Adi Putra. Process Simulation on Fast Pyrolysis of Palm Kernel... | 68

Table 3. Predicted chemical reactions for hydrodeoxygenation process

\begin{tabular}{|c|c|c|c|}
\hline Eq & Reaction & Conversion(X) & References \\
\hline (1) & $\mathrm{C}_{2} \mathrm{H}_{4} \mathrm{O}_{2}+2 \mathrm{H}_{2} \longrightarrow \mathrm{C}_{2} \mathrm{H}_{6} \mathrm{O}+\mathrm{H}_{2} \mathrm{O}$ & 0.55 & (Chen et al., 2011) \\
\hline (2) & $\mathrm{C}_{2} \mathrm{H}_{4} \mathrm{O}_{2}+4 \mathrm{H}_{2} \longrightarrow 2 \mathrm{CH}_{4}+2 \mathrm{H}_{2} \mathrm{O}$ & 0.17 & \\
\hline (3) & $\mathrm{C}_{2} \mathrm{H}_{4} \mathrm{O}_{2}+3 \mathrm{H}_{2} \longrightarrow \mathrm{C}_{2} \mathrm{H}_{6}+2 \mathrm{H}_{2} \mathrm{O}$ & 0.0092 & \\
\hline (4) & $\mathrm{C}_{5} \mathrm{H}_{4} \mathrm{O}_{2}+\mathrm{H}_{2} \longrightarrow \mathrm{C}_{5} \mathrm{H}_{6} \mathrm{O}_{2}$ & 0.055 & (Wang et al., 2018) \\
\hline (5) & $\mathrm{C}_{5} \mathrm{H}_{4} \mathrm{O}_{2}+2 \mathrm{H}_{2} \longrightarrow \mathrm{C}_{5} \mathrm{H}_{6} \mathrm{O}+\mathrm{H}_{2} \mathrm{O}$ & 0.539 & \\
\hline (6) & $\mathrm{C}_{5} \mathrm{H}_{4} \mathrm{O}_{2}+5 \mathrm{H}_{2} \longrightarrow \mathrm{C}_{5} \mathrm{H}_{12} \mathrm{O}+\mathrm{H}_{2} \mathrm{O}$ & 0.058 & \\
\hline (7) & $\mathrm{C}_{5} \mathrm{H}_{4} \mathrm{O}_{2}+4 \mathrm{H}_{2} \longrightarrow \mathrm{C}_{5} \mathrm{H}_{10} \mathrm{O}+\mathrm{H}_{2} \mathrm{O}$ & 0.196 & \\
\hline (8) & $\mathrm{C}_{5} \mathrm{H}_{4} \mathrm{O}_{2}+4 \mathrm{H}_{2} \longrightarrow \mathrm{C}_{5} \mathrm{H}_{10} \mathrm{O}_{2}$ & 0.022 & \\
\hline (9) & $\mathrm{C}_{4} \mathrm{H}_{8} \mathrm{O}+2 \mathrm{H}_{2} \longrightarrow \mathrm{C}_{4} \mathrm{H}_{10}+\mathrm{H}_{2} \mathrm{O}$ & 0.85 & (King et al., 2015) \\
\hline (10) & $\mathrm{C}_{5} \mathrm{H}_{8} \mathrm{O}_{2}+\mathrm{H}_{2} \longrightarrow \mathrm{C}_{5} \mathrm{H}_{10} \mathrm{O}_{2}$ & 0.80 & (Hu et al., 2015) \\
\hline (11) & $\mathrm{C}_{5} \mathrm{H}_{8} \mathrm{O}+2 \mathrm{H}_{2} \longrightarrow \mathrm{C}_{5} \mathrm{H}_{10}+\mathrm{H}_{2} \mathrm{O}$ & 0.60 & (Liu et al., 2013) \\
\hline (12) & $\mathrm{C}_{5} \mathrm{H}_{8} \mathrm{O}+\mathrm{H}_{2} \longrightarrow \mathrm{C}_{5} \mathrm{H}_{8} \mathrm{O}+\mathrm{H}_{2} \mathrm{O}$ & 0.145 & \\
\hline (13) & $\mathrm{C}_{5} \mathrm{H}_{8} \mathrm{O}+\mathrm{H}_{2} \longrightarrow \mathrm{C}_{5} \mathrm{H}_{8}+\mathrm{H}_{2} \mathrm{O}$ & 0.254 & \\
\hline (14) & $\mathrm{C}_{6} \mathrm{H}_{6} \mathrm{O}+4 \mathrm{H}_{2} \longrightarrow \mathrm{C}_{6} \mathrm{H}_{12}+\mathrm{H}_{2} \mathrm{O}$ & 0.80 & (Zhang et al., 2014) \\
\hline (15) & $\mathrm{C}_{6} \mathrm{H}_{6} \mathrm{O}+3 \mathrm{H}_{2} \longrightarrow \mathrm{C}_{6} \mathrm{H}_{12} \mathrm{O}$ & 0.10 & \\
\hline (16) & $\mathrm{C}_{7} \mathrm{H}_{8} \mathrm{O}+4 \mathrm{H}_{2} \longrightarrow \mathrm{C}_{7} \mathrm{H}_{14}+\mathrm{H}_{2} \mathrm{O}$ & 0.543 & (Whiffen and Smith, 2012) \\
\hline (17) & $\mathrm{C}_{7} \mathrm{H}_{8} \mathrm{O}+\mathrm{H}_{2} \longrightarrow \mathrm{C}_{7} \mathrm{H}_{8}+\mathrm{H}_{2} \mathrm{O}$ & 0.457 & \\
\hline (18) & $\mathrm{C}_{7} \mathrm{H}_{8} \mathrm{O}_{2}+\mathrm{H}_{2} \longrightarrow \mathrm{C}_{6} \mathrm{H}_{6} \mathrm{O}_{2} \mathrm{CH}_{4}$ & 0.05 & (Mora-Vergara et al., 2018) \\
\hline (19) & $\mathrm{C}_{7} \mathrm{H}_{8} \mathrm{O}_{2}+2 \mathrm{H}_{2} \longrightarrow \mathrm{C}_{6} \mathrm{H}_{6} \mathrm{O}+\mathrm{H}_{2} \mathrm{O}+\mathrm{CH}_{4}$ & 0.55 & \\
\hline (20) & $\mathrm{C}_{7} \mathrm{H}_{8} \mathrm{O}_{2}+3 \mathrm{H}_{2} \longrightarrow \mathrm{C}_{6} \mathrm{H}_{6}+2 \mathrm{H}_{2} \mathrm{O}+\mathrm{CH}_{4}$ & 0.15 & \\
\hline (21) & $\mathrm{C}_{7} \mathrm{H}_{8} \mathrm{O}_{2}+2 \mathrm{H}_{2} \longrightarrow \mathrm{C}_{7} \mathrm{H}_{8}+2 \mathrm{H}_{2} \mathrm{O}$ & 0.05 & \\
\hline (22) & $\mathrm{C}_{7} \mathrm{H}_{8} \mathrm{O}_{2}+\mathrm{H}_{2} \longrightarrow \mathrm{C}_{7} \mathrm{H}_{8} \mathrm{O}+\mathrm{H}_{2} \mathrm{O}$ & 0.15 & \\
\hline (23) & $\mathrm{C}_{8} \mathrm{H}_{10} \mathrm{O}_{2}+3 \mathrm{H}_{2} \longrightarrow \mathrm{C}_{7} \mathrm{H}_{8}+2 \mathrm{H}_{2} \mathrm{O}$ & 0.025 & (Hsu and Lin, 2017) \\
\hline (24) & $\mathrm{C}_{8} \mathrm{H}_{10} \mathrm{O}_{2}+2 \mathrm{H}_{2} \longrightarrow \mathrm{C}_{7} \mathrm{H}_{8} \mathrm{O}+\mathrm{H}_{2} \mathrm{O}+\mathrm{CH}_{4}$ & 0.12 & \\
\hline (25) & $\mathrm{C}_{8} \mathrm{H}_{10} \mathrm{O}_{2}+2 \mathrm{H}_{2} \longrightarrow \mathrm{C}_{7} \mathrm{H}_{14} \mathrm{O}+\mathrm{H}_{2} \mathrm{O}+\mathrm{CH}_{4}$ & 0.151 & \\
\hline (26) & $\mathrm{C}_{8} \mathrm{H}_{10} \mathrm{O}_{2}+6 \mathrm{H}_{2} \longrightarrow \mathrm{C}_{7} \mathrm{H}_{14}+2 \mathrm{H}_{2} \mathrm{O}+\mathrm{CH}_{4}$ & 0.613 & \\
\hline (27) & $\mathrm{C}_{6} \mathrm{H}_{6} \mathrm{O}_{2}+6 \mathrm{H}_{2} \longrightarrow \mathrm{C}_{6} \mathrm{H}_{6} \mathrm{O}+\mathrm{H}_{2} \mathrm{O}$ & 1 & (Gao et al., 2015) \\
\hline (28) & $\mathrm{C}_{9} \mathrm{H}_{12} \mathrm{O}_{2}+6 \mathrm{H}_{2} \longrightarrow \mathrm{C}_{8} \mathrm{H}_{16}+\mathrm{CH}_{4}+2 \mathrm{H}_{2} \mathrm{O}$ & 0.94 & (Chen, et al., 2015) \\
\hline (29) & $\mathrm{C}_{9} \mathrm{H}_{12} \mathrm{O}_{2}+5 \mathrm{H}_{2} \longrightarrow \mathrm{C}_{8} \mathrm{H}_{16} \mathrm{O}+\mathrm{CH}_{4}+\mathrm{H}_{2} \mathrm{O}$ & 0.01 & \\
\hline (30) & $\mathrm{C}_{8} \mathrm{H}_{10} \mathrm{O}_{3}+2 \mathrm{H}_{2} \longrightarrow \mathrm{C}_{7} \mathrm{H}_{8} \mathrm{O}_{2}+\mathrm{CH}_{4}+\mathrm{H}_{2} \mathrm{O}$ & 0.626 & (Zhang et al., 2016) \\
\hline (31) & $\mathrm{C}_{8} \mathrm{H}_{10} \mathrm{O}_{3}+7 \mathrm{H}_{2} \longrightarrow \mathrm{C}_{6} \mathrm{H}_{12} \mathrm{O}+2 \mathrm{CH}_{4}+2 \mathrm{H}_{2} \mathrm{O}$ & 0.056 & \\
\hline
\end{tabular}


Table 3 (continued). Predicted chemical reactions for hydrodeoxygenation process

\begin{tabular}{clcl}
\hline Eq & \multicolumn{1}{c}{ Reaction } & Conversion(X) & References \\
\hline (32) & $\mathrm{C}_{10} \mathrm{H}_{12} \mathrm{O}_{2}+7 \mathrm{H}_{2} \longrightarrow \mathrm{C}_{9} \mathrm{H}_{18}+2 \mathrm{H}_{2} \mathrm{O}+\mathrm{CH}_{4}$ & 0.94 & (Chen et al., 2015) \\
(33) & $\mathrm{C}_{10} \mathrm{H}_{12} \mathrm{O}_{2}+6 \mathrm{H}_{2} \longrightarrow \mathrm{C}_{9} \mathrm{H}_{18} \mathrm{O}+\mathrm{H}_{2} \mathrm{O}+\mathrm{CH}_{4}$ & 0.01 & \\
\hline (34) & $\mathrm{C}_{12} \mathrm{H}_{8} \mathrm{O}+6 \mathrm{H}_{2} \longrightarrow \mathrm{C}_{12} \mathrm{H}_{20} \mathrm{O}$ & 0.05 & (Wang et al., 2013) \\
${ }_{(35)}$ & $\mathrm{C}_{12} \mathrm{H}_{8} \mathrm{O}+8 \mathrm{H}_{2} \longrightarrow \mathrm{C}_{12} \mathrm{H}_{22}+\mathrm{H}_{2} \mathrm{O}$ & 0.90 & \\
\hline${ }^{\mathrm{a}}(36)$ & $\mathrm{C}_{3} \mathrm{H}_{6} \mathrm{O}_{2}+3 \mathrm{H}_{2} \longrightarrow \mathrm{C}_{3} \mathrm{H}_{8}+2 \mathrm{H}_{2} \mathrm{O}$ & 0.779 & (Bridgwater, 2012) \\
${ }_{\text {a(37) }}$ & $\mathrm{C}_{6} \mathrm{H}_{14} \mathrm{O}+\mathrm{H}_{2} \longrightarrow \mathrm{C}_{6} \mathrm{H}_{14}+\mathrm{H}_{2} \mathrm{O}$ & 0.779 & \\
${ }^{\mathrm{a}}(38)$ & $\mathrm{C}_{5} \mathrm{H}_{8} \mathrm{O}_{2}+4 \mathrm{H}_{2} \longrightarrow \mathrm{C}_{5} \mathrm{H}_{12}+2 \mathrm{H}_{2} \mathrm{O}$ & 0.779 & \\
\hline
\end{tabular}

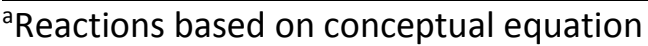

Table 4. Process condition for the simulated unit opeartions

\begin{tabular}{lccc}
\hline Process & $\begin{array}{c}\text { Temperature } \\
\left({ }^{\circ} \mathbf{C}\right)\end{array}$ & Pressure (atm) & Ref \\
\hline Pyrolysis & 500 & 1 & (Nurul Islam et al., 1999) \\
Condenser & 0 & 1 & \\
Hydrodeoxygenation (HDO) & 400 & 103 & (Elliott et al., 2009) \\
\hline
\end{tabular}

\section{RESULTS AND DISCUSSION}

\subsection{Process description}

The entire process is categorised into five parts as shown in the process flow diagram in Figures $\mathbf{2}$ and $\mathbf{3}$. Firstly, palm kernel shell (PKS) is fed into a grinder at $12500 \mathrm{~kg} / \mathrm{h}$. The feed is ground and sieved to $500 \mu \mathrm{m}$ prior to pyrolysis. Lastly, the feed is dried. Drying is to reduce the moisture content of the feed to less than 10 wt\% (Wright et al., 2010).

After pretreatment, the feed enters the pyrolysis reactor, where it is degraded at $500^{\circ} \mathrm{C}$ to produce gas, char and oil. Following pyrolysis, the products are sent to a cyclone where $90 \%$ of the solids are removed and condensed at $0^{\circ} \mathrm{C}$ to collect the bio oil produced. The bio oil is then sent to the decanter to separate the aqueous phase from the organic phase. Next, the bio oil is fed along with hydrogen into a hydrodeoxygenation (HDO) reactor. The hydrodeoxygenation reactor operates at $400^{\circ} \mathrm{C}$ and $103 \mathrm{~atm}$.

The products, as stated in Table 4, are then sent for a series of separation to obtain the final output. The light gasses are firstly removed as vapor and distillate in DC 1 . Major component, cyclohexane and the components with lesser boiling point are separated from the heavies in DC 2, followed by water removal in decanter, B5. the concentrated oil is then fed to DC 3 where methyl cyclohexane is purified up to its azeotropic composition. Lastly, in DC 4 the azeotropic components are separated and the final output with carbon number ranging from $C_{5}$ to $C_{7}$ is obtained.

The bottom of DC 2 is fed into DC 5 where the major component bicyclohexyl is separated at the bottom which is then further purified in DC 6. Distillate of DC 5 is fed to DC 7, where the ethyl cyclohexane and propyl cyclohexane are removed from the 
heavies, consisting of unreacted raw cyclohexane are separated from the materials. Water is removed as the distillate remaining impurities. All the liquid of DC 8 while the bottom is sent to DC 9 hydrocarbons are then mixed to form liquid where ethyl cyclohexane and propyl fuels with carbon ranging from $C_{5}$ to $C_{12}$.

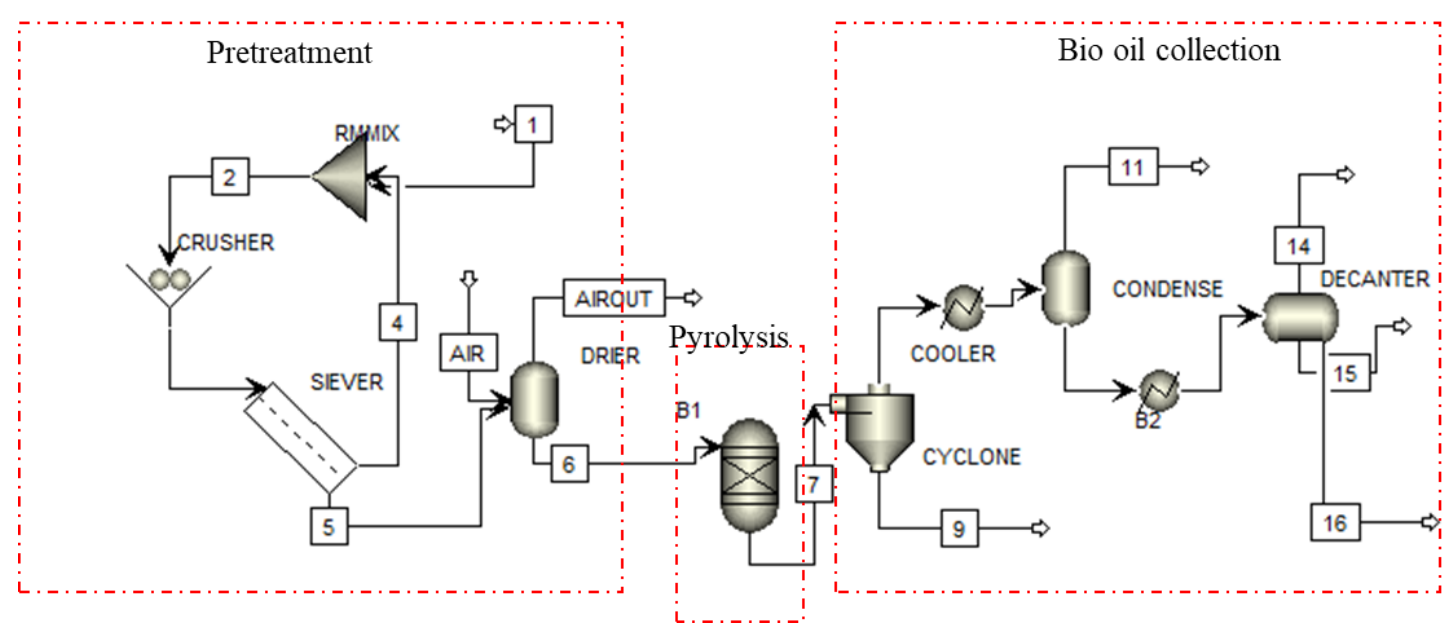

Figure 2. Process flow diagram for fast pyrolysis

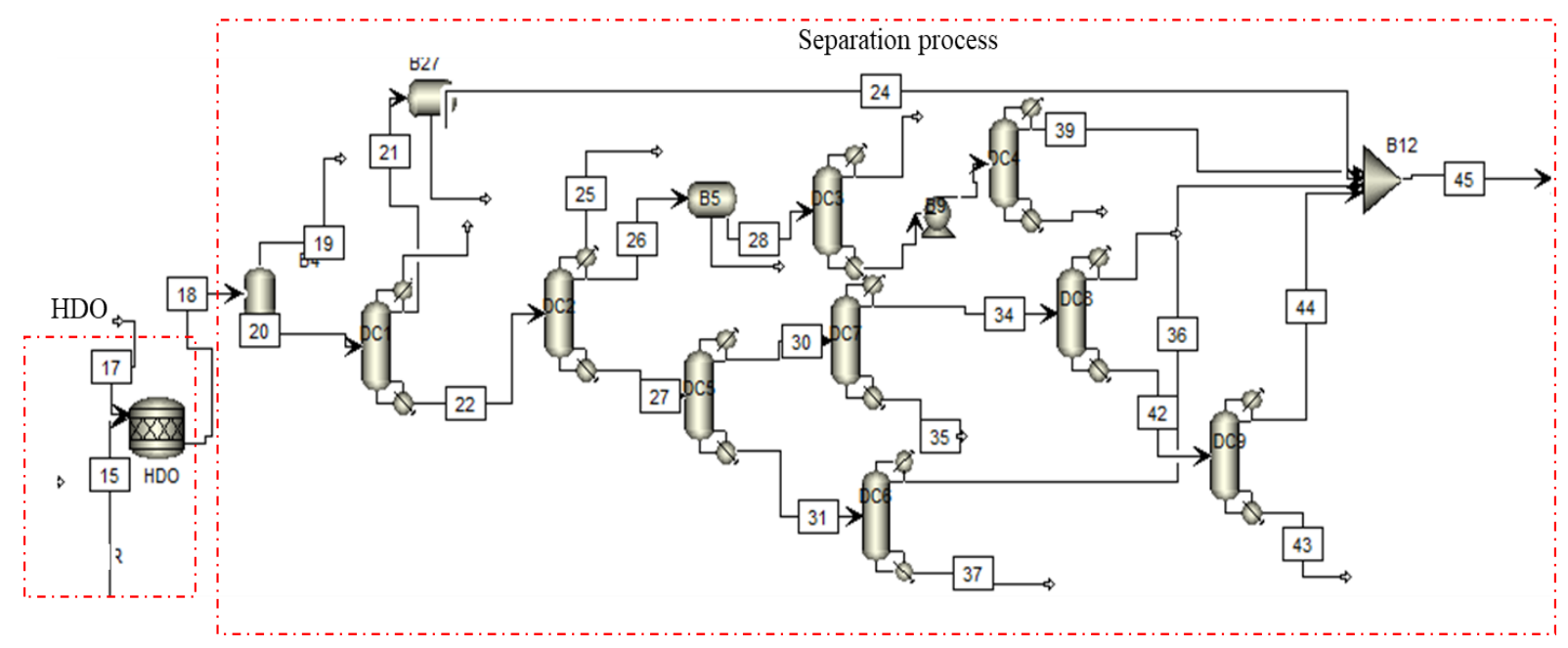

Figure 3. Process flow diagram for hydrodeoxygenation and separation process

\subsection{Comparison on distillate curve}

Distillate curve of the simulated process is constructed using the model analysis tool of Aspen Plus based on the hydrocarbons ( $C_{5}$ to $C_{12}$ ) obtained.

The graphical comparison between ASTM of gasoline and the simulated processs is shown in Figure 4. From the comparison, it is observed that at lower temperature $\left(<100^{\circ} \mathrm{C}\right)$ simulated process have lesser lights compared to the ASTM of gasoline. On the other hand, beyond $100^{\circ} \mathrm{C}$ the simulated process has more heavies compared to the ASTM of gasoline.

No doubt, the upgraded oil can indeed be used as fuel. Since, the difference on the comparison between the ASTM of gasoline and upgraded oil has not much significance. 


\section{CONCLUSION}

This is a preliminary study that simulate a complete fast pyrolysis of palm kernel shell process including the upgrading of the bio oil produced. For the upgrading methods, hydrodeoxygenation is used. The chemical reactions involved in the hydrodeoxygenation process for palm kernel shell is unavailable in the literature. Hence, it was synthesized based on hydrodeoxygenation of pyrolysis oil from different biomass as the final product would be the same (Elliott et al., 2009). From the synthesised chemical reactions, it was observed that the highest carbon number found in the pyrolysis oil from palm kernel shell is $C_{12}$. Thus, there are no diesel range hydrocarbon available from the pyrolysis oil. From the simulation, distillate curves that compares the simulated process with the ASTM of gasoline are obtained. The distillate curve shows that at lower temperatures $\left(<100^{\circ} \mathrm{C}\right)$, the simulated results have lesser lights compared to the ASTM of gasoline and the otherwise is observed at higher temperature $\left(>100^{\circ} \mathrm{C}\right)$.

\section{ACKNOWLEDGEMENTS}

We would like to thank Universiti Teknologi PETRONAS for giving us the opportunity to carry out this project.

\section{AUTHORS' NOTE}

We declare that there is no conflict of interest regarding the publication of this article. We have confirmed that the data and the paper are free of plagiarism.

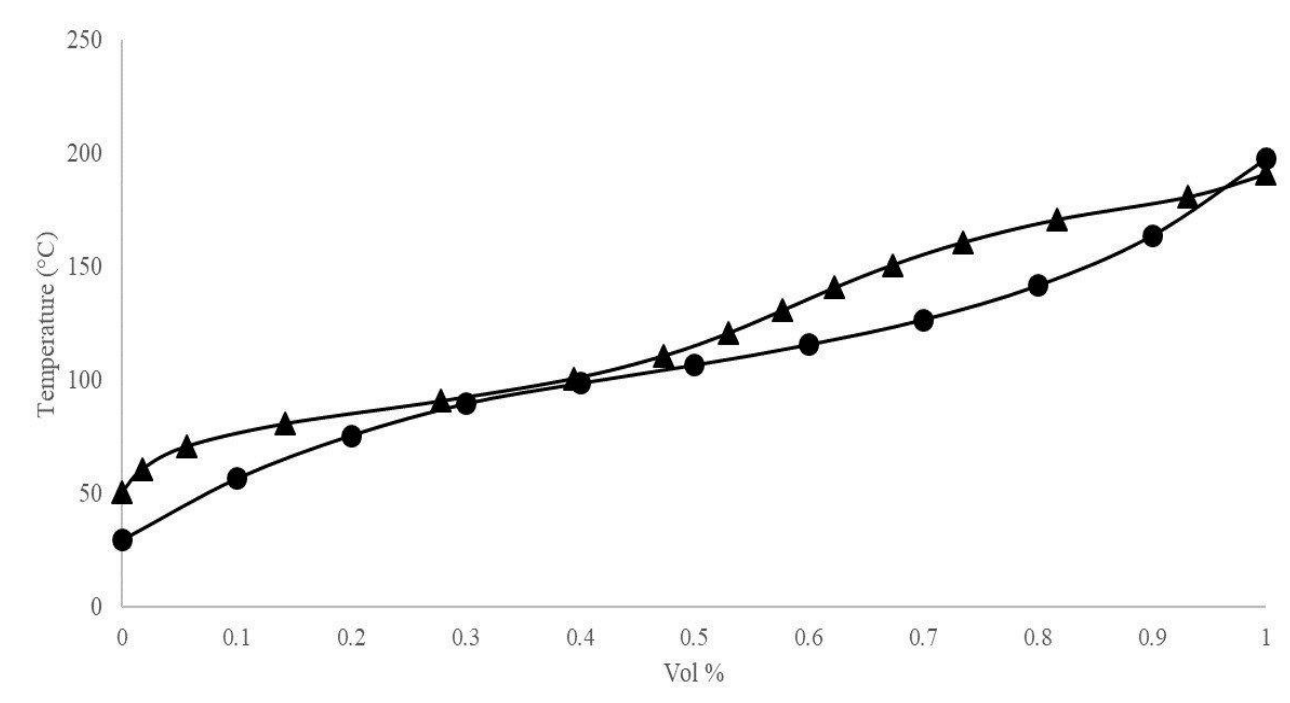

Figure 4. Distillate curve of ASTM gasoline ( $\mathrm{O}$ ) and simulated process ( $\Delta$ ) process

\section{REFERENCES}

Andika, R., and Valentina, V. (2016). Techno-economic Assessment of Coal to SNG Power Plant in Kalimantan. Indonesian Journal of Science and Technology, 1(2), 156-169.

Awalludin, M.F., Sulaiman, O., Hashim, R., and Nadhari, W.N.A.W. (2015). An overview of the oil palm industry in Malaysia and its waste utilization through thermochemical conversion, specifically via liquefaction. Renewable and Sustainable Energy Reviews, 50, 1469-1484. 
Bhullar, L.K., and Putra, Z.A. (2017). Process Design and Modelling of the Production of Butyl Cellosolve Acetate and EO-3 Phosphate Ester. Indonesian Journal of Science and Technology, 2(2), 166-182.

Bridgwater, A.V. (2012). Review of fast pyrolysis of biomass and product upgrading. Biomass and Bioenergy, 38, 68-94.

Chen, L., Zhu, Y., Zheng, H., Zhang, C., Zhang, B., and Li, Y. (2011). Aqueous-phase hydrodeoxygenation of carboxylic acids to alcohols or alkanes over supported $\mathrm{Ru}$ catalysts. Journal of Molecular Catalysis A: Chemical, 351, 217-227.

Chen, M.-Y., Huang, Y.-B., Pang, H., Liu, X.-X., and Fu, Y. (2015). Hydrodeoxygenation of ligninderived phenols into alkanes over carbon nanotube supported Ru catalysts in biphasic systems. Green Chemistry, 17(3), 1710-1717.

Elliott, D.C., Hart, T.R., Neuenschwander, G.G., Rotness, L.J., and Zacher, A.H. (2009). Catalytic hydroprocessing of biomass fast pyrolysis bio-oil to produce hydrocarbon products. Environmental Progress and Sustainable Energy, 28(3), 441-449.

Gao, D., Xiao, Y., and Varma, A. (2015). Guaiacol Hydrodeoxygenation over Platinum Catalyst: Reaction Pathways and Kinetics. Industrial and Engineering Chemistry Research, 54(43), 10638-10644.

Hsu, P.-J., and Lin, Y.-C. (2017). Hydrodeoxygenation of 4-methylguaiacol over silicasupported nickel phosphide catalysts: The particle size effect. Journal of the Taiwan Institute of Chemical Engineers, 79, 80-87.

Hu, C., Creaser, D., Grönbeck, H., Ojagh, H., and Skoglundh, M. (2015). Selectivity and kinetics of methyl crotonate hydrogenation over Pt/Al203. Catalysis Science and Technology, 5(3), 1716-1730.

King, A.E., Brooks, T.J., Tian, Y.-H., Batista, E.R., and Sutton, A.D. (2015). Understanding Ketone Hydrodeoxygenation for the Production of Fuels and Feedstocks From Biomass. ACS Catalysis, 5(2), 1223-1226.

Lim, X.Y., and Andrésen, J.M. (2011). Pyro-catalytic deoxgenated bio-oil from palm oil empty fruit bunch and fronds with boric oxide in a fixed-bed reactor. Fuel Processing Technology, 92(9), 1796-1804.

Liu, H., Wang, W., Zhang, X., Yang, Y., Zhang, K., Peng, H., and Luo, H. (2013). Hydrodeoxygenation of cyclopentanone over Ni-W-B amorphous catalyst: effect of $\mathrm{Cr}$ and Ce. Reaction Kinetics, Mechanisms and Catalysis, 109(2), 537-549.

Luo, Y., Guda, V.K., Hassan, E.B., Steele, P.H., Mitchell, B., and Yu, F. (2016). Hydrodeoxygenation of oxidized distilled bio-oil for the production of gasoline fuel type. Energy Conversion and Management, 112, 319-327.

Marker, T.L., Felix, L.G., Linck, M.B., and Roberts, M.J. (2012). Integrated hydropyrolysis and hydroconversion $(\mathrm{IH} 2)$ for the direct production of gasoline and diesel fuels or blending components from biomass, part 1: Proof of principle testing. Environmental Progress and Sustainable Energy, 31(2), 191-199. 
Mora-Vergara, I.D., Hernández Moscoso, L., Gaigneaux, E.M., Giraldo, S.A., and BaldovinoMedrano, V.G. (2018). Hydrodeoxygenation of guaiacol using NiMo and CoMo catalysts supported on alumina modified with potassium. Catalysis Today, 302, 125135.

Nurul Islam, M., Zailani, R., and Nasir Ani, F. (1999). Pyrolytic oil from fluidised bed pyrolysis of oil palm shell and itscharacterisation. Renewable Energy, 17(1), 73-84.

Putra, Z.A. (2016a). Early Phase Process Evaluation: Industrial Practices. Indonesian Journal of Science and Technology, 1(2), 238-248.

Putra, Z.A. (2016b). Use of Process Simulation for Plant Debottlenecking. Indonesian Journal of Science and Technology, 1(1), 74-81.

Wang, C., Luo, J., Liao, V., Lee, J. D., Onn, T.M., Murray, C.B., and Gorte, R.J. (2018). A comparison of furfural hydrodeoxygenation over $\mathrm{Pt}-\mathrm{Co}$ and Ni-Fe catalysts at high and low H2 pressures. Catalysis Today, 302, 73-79.

Wang, L., Zhang, M., Zhang, M., Sha, G., and Liang, C. (2013). Hydrodeoxygenation of Dibenzofuran over Mesoporous Silica COK-12 Supported Palladium Catalysts. Energy and Fuels, 27(4), 2209-2217.

Whiffen, V.M.L., and Smith, K.J. (2012). A Comparative Study of 4-Methylphenol Hydrodeoxygenation Over High Surface Area MoP and Ni<Subscript $>2</$ Subscript $>\mathrm{P}$. Topics in Catalysis, 55(14-15), 981-990.

Wright, M.M., Daugaard, D.E., Satrio, J.A., and Brown, R.C. (2010). Techno-economic analysis of biomass fast pyrolysis to transportation fuels. Fuel, 89(Supplement 1), S2-S10.

Xiu, S., and Shahbazi, A. (2012). Bio-oil production and upgrading research: A review. Renewable and Sustainable Energy Reviews, 16(7), 4406-4414.

Zacher, A.H., Olarte, M.V., Santosa, D.M., Elliott, D.C., and Jones, S.B. (2014). A review and perspective of recent bio-oil hydrotreating research. Green Chemistry, 16(2), 491-515.

Zhang, C., Qi, J., Xing, J., Tang, S.-F., Song, L., Sun, Y., and Li, X. (2016). An investigation on the aqueous-phase hydrodeoxygenation of various methoxy-substituted lignin monomers on Pd/C and HZSM-5 catalysts. RSC Advances, 6(106), 104398-104406.

Zhang, W., Chen, J., Liu, R., Wang, S., Chen, L., and Li, K. (2014). Hydrodeoxygenation of LigninDerived Phenolic Monomers and Dimers to Alkane Fuels over Bifunctional ZeoliteSupported Metal Catalysts. ACS Sustainable Chemistry and Engineering, 2(4), 683-691. 